\title{
Islamic Finance as Social Finance: A Bibliometric Analysis from 2000 to 2021
}

\author{
Federica Lanzara ${ }^{1}$ \\ ${ }^{1}$ Department of Management, University of Turin, Italy \\ Correspondence: Federica Lanzara, Department of Management, University of Turin, Italy. E-mail: \\ federica.lanzara@unito.it \\ Received: May 30, 2021 \\ Accepted: July 20, 2021 \\ Online Published: August 12, 2021 \\ doi:10.5539/ijbm.v16n9p107 \\ URL: https://doi.org/10.5539/ijbm.v16n9p107
}

\begin{abstract}
The main purpose of this research is to map the academic contribution of social finance to the discussion in the field of Islamic finance.

An analysis of 788 contributions published in international academic journals, books review and chapters, editorial material and proceedings papers has been done using the bibliometric method.

The findings show that there are a number of journals that have had a higher production on the topic with an impact on research and, furthermore, it emerges that the works of the most relevant authors are made with qualitative methods that have been the most used to demonstrate the link between Islamic finance and social finance. The analysis also shows that the relation between Islamic finance and social finance is linked, among the others, to the words PERFORMANCE, IMPACT RISK, OWNERSHIP, CORPORATE SOCIAL-RESPONSIBILITY, MANAGEMENT, BEHAVIOR and EFFICIENCY, demonstrating that there is also a link with Sustainable Development Goals (SDGs). It has also been observed the keyword evolution through the years which proved a dramatic increase on the academic attention to the topic particularly in the last five years.
\end{abstract}

Research limitations/implications - The paper's main limitation is due to the adoption of the bibliometric method because the databases include only part of the scientific papers and not all world's sources. However, WOS database, the one adopted for the research, is the world's most complete index even though it is not complete at all. On the other hand, to have a wider landscape of knowledge on the field of research, they have been considered all kind of sources: papers published in international and academic journals, books chapters and reviews, editorial materials and proceedings papers. The implications for academics, institutions, banks, enterprises and customers seem to be very relevant because it is assumed that a lot of work on the field must be done to strengthen the practical relation between Islamic finance and social finance.

Originality/value - This research highlights the increasing relation, from an academic point of view, between Islamic finance and social finance has increased in the last 21 years, especially in the last 5 . According to the literature, social finance is a relevant aspect in the present academic discussion on Islamic finance. For these reasons, to map the researches that have been done in this field, the study analyzes the relationship between Islamic finance and social finance.

Keywords: bibliometrics analysis, Islamic finance, social finance

\section{Introduction}

Islamic finance has emerged in the last decades as an instrument of alternative finance (Pollard e Samers 2007). Before 1980, literature and interest on this field were quite scarce, but in the recent years, however, Islamic finance is considered as one of the most interesting vehicles of a financial change with hypothetical unlimited outputs in the real economy (Belouafi e Chachi 2014; Ferro 2005; Hajjar 2019; Masiukiewicz 2017; Nawaz et al. 2019). As highlighted in previous studies, in this sector there are still gaps in our knowledge of whether and how Islamic finance will grow (Hassan e Aliyu 2018; Hassan, Aliyu, e Hussain 2019). In particular, it has been observed a growing interest on the social aspects of Islamic finance (Biancone \& Radwan 2018; Cattelan, 2018; World Bank and Islamic Development Bank Group, 2017). To enrich the knowledge on the relation between 
Islamic finance and social finance, this research analyzes the literature evolution from 2000 until 2021 in order to fill a gap of knowledge in the specific field.

In order to face social and economic challenges, particularly after 2008 and COVID-19 crisis, it seems necessary to have a deeper knowledge of all the possible instruments which can be a real alternative for sustainable growth and wealth balance. In that sense, the social attitude of the Islamic financial movement is relevant (Faturohman et al., 2021; Haji-Othman, Latib, \& Ahmad, 2020).

Performance (64), impact (39) and risk (39), as it emerges from the research, are the most relevant keywords in the considered documents, confirming the assumption that in the relation between Islamic finance and social finance, all the parties have an interest on the performances of their activities with an eye on their impact and on the related risks.

The research mainly focuses on the relation of Islamic finance as social finance using a bibliometric approach and taking into account years from 2000 to 2021. This range of years has been chosen to evaluate the most recent and relevant contribution on the field. 788 documents published in international and academic journals, editorial materials, reviews and proceedings papers had been analyzed in their characteristics, citation patterns and content.

According to (Zupic \& Čater, 2015), there is a number of possible questions that could be answered by different bibliometric methods. According to that indications, in this paper it has been conducted a Citation analysis and a Co-word analysis (Figure 1).

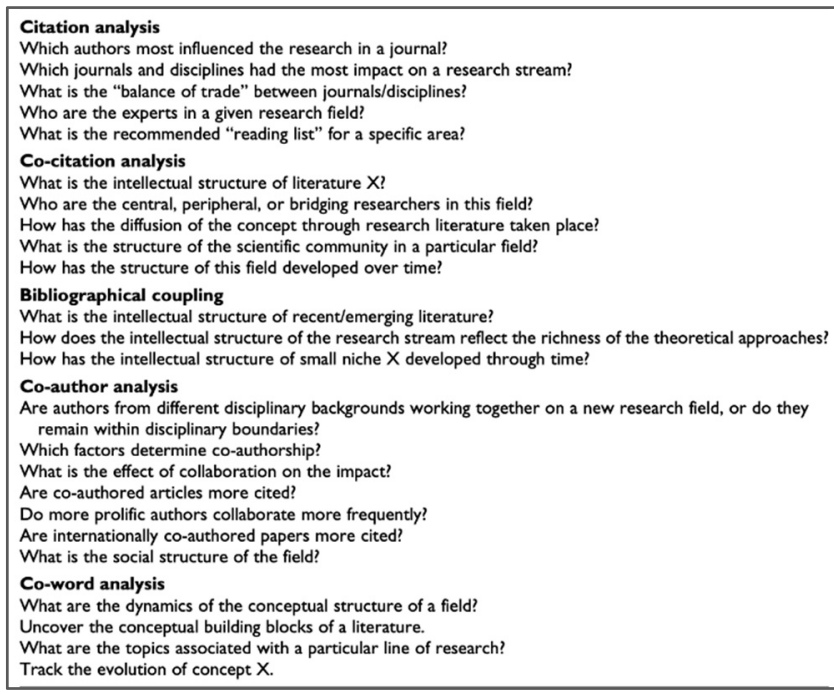

Figure 1. Research questions answered by different bibliometric methods

Source: Extract from "Bibliometric Methods in Management and Organization” (Zupic \& Čater, 2015)

Furthermore, this paper aims also (a) to demonstrate the relation in literature between Islamic finance and social finance, (b) to crystallize the contents of the most relevant academic studies and (c) to analyze the evolution of the perception of the social aspect of Islamic finance in literature.

In order to map the studies that have been done regarding the relation between Islamic finance and social finance among the last 21 years, the paper explores how research has been done.

To explore the contents of this relationship in the academic contribution and also to pinpoint the main streams of the academic research, the research is held as follows:

(i) Literature analysis;

(ii) Detection of the most relevant articles;

(iii) Keywords analysis.

The following section will present the methodology and will include a review of the state of the art in the literature regarding relation between Islamic finance and social finance. The third section will analyze the results 
and findings and the last section will outline the implications and conclusions.

This bibliometric analysis obtains the following objectives:

(a) Provides bibliometric information on 788 scientific studies extracted from WOS database;

(b) Uses the bibliometric R-package and Biblioshiny to obtain and record the quantitative data of different selected articles;

(c) Uses variables such as main information, source growth, annual scientific production, most relevant sources, top 20 authors and top 20 Universities cited to identify the publication pattern;

(d) Uses citations analysis and country production map to understand the network of this research stream;

(e) Studies the keyword co-occurrency network to evaluate the most relevant topics on the field of study.

\subsection{Background}

Starting from the assumption that Islamic finance is a declination of ethical finance for its link with Islam as a religion, it seemed interesting to deepen the research on the link between Islamic finance and social finance from a quantitative point of view, analyzing the specific literature on the theme.

Islamic finance operates on the basis of Islamic principles, which have a strong social footing, with the target to create shared value within society. These principles can be found in Quran, in the Sunnah and in secondary laws which altogether form Sharia. So, Sharia governs all financial and business services in Muslim countries and all the financial tools related to Islamic finance that spread in non-Muslim countries in the last 30 years. This spread in non-Muslim countries could be driven, in the future, by the Islamic finance attitude towards social finance which is, as an instance, one of the new economic challenges for mainstream finance through the creation of a more inclusive and sustainable financial framework for global growth and wellness.

Furthermore, in order to understand the strong relation between Islamic finance and Social finance, it must be taken under consideration the very old link existing between Islam and economy. In fact, according to Thompson (Thompson 2007), "the number of words borrowed from contemporaneous commercial usage that appear in the Qur'ân (Torrey 1892), along with the various hadith devoted to economic principles, reflect the ubiquitous role of commerce in the earliest stages of Islam's development, leaving "no doubt that the believers were engaged in, indeed preoccupied with, trade (Crone 2005)" and also "Islam grew out of a highly conducive trading environment, where economic concerns were central in the minds of the first converts." Following that assumptions, Islamic finance seem to be the perfect environment for social finance due to the link between Islam, ethics and economy.

Moreover, according to Mohamad (2014), there is a direct link between SRI (Social Responsible Investments) (Note 1) and Islamic investments due to the fact that they are "regarded as SRI since it applies an ethical screening process that excludes certain industries" (BINMAHFOUZ 2012).

Finally, Islamic finance could be seen as a declination of social finance also due to its compliance with the Sustainable Development Goals (SDGs) developed by the UN which recognize and ratify the key social, economic and environmental issues of our society. SDGs, as a matter of fact, must be used from all private and public actors as the basis for developing the public implementation (Farneti et al., 2019).

However, literature in the field appears to be very limited (Littlewood e Holt 2018), so an important academic discourse with a focus on these themes is highly recommended to achieve relevant advances in the achievement of global goals and in the attainment of the criteria of 2030 Agenda for Sustainable Development.

\section{Methodology}

\subsection{Method}

The research was carried out as a bibliometric analysis. This method allows researchers to determine necessary information about the literature about a specific research topic (Zupic \& Čater, 2015), including, among the others, (1) type of documents, (2) annual scientific production, (3) scientific sources, (4) source growth, (5) author's keywords, (8) topic dendrogram, (9) articles' citations and (10) country's production. Verbeek, Debackere, Luwel, and Zimmermann (2002), define bibliometric analysis as follows: "Bibliometrics is the statistical analysis of scholarly communication through publications". To perform a rigorous bibliometric and network analysis (e.g., citation and citation analysis) with the aim of tracing the knowledge structure of this topic, all sources have been used.

For this reason, the meta-search engine Web of Science-WOS was deployed to access the most important academic databases which contain the widest variety of key articles for scientific analysis (Okoli \& Schabram, 
2010; Webster \& Watson, 2002).

The bibliometric tool for network analysis has proved useful to target consolidated and emerging areas of research (Aria \& Cuccurullo, 2017) and also to give contribution towards integrating these elements in literature (Secinaro et al., 2020).

The keywords used to perform the bibliometric study were "Islamic finance and social finance". Consequently, the research's results were pooled into a one list through the creation of a bib file for the Data Analysis which has been performed with R-Studio. Biblioshiny tool was used for the creation of conceptual maps of the Data Analysis. Software R-Studio has been chosen to do the statistical analyses since it has been considered useful to perform science mapping analysis (Aria \& Cuccurullo, 2017).

The above-mentioned process is represented in Figure 2.

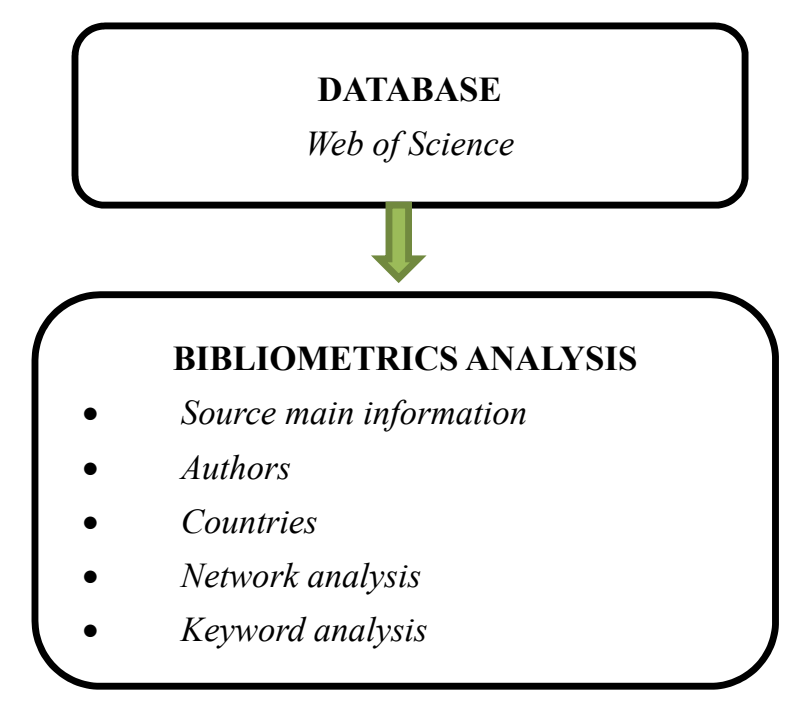

Figure 2. Methodology framework

Source: personal elaboration.

\subsection{Paper Identification}

Seven hundred and eighty-eight (788) contributions have been identified in the WOS database based on the research criteria.

For this extent, they have been included articles dealing within all areas of knowledge including also non peer reviewed ones. In order to answer the research question and to limit the research to a more recent but even wider period, documents published from 2000 to 2021 (February 2021) have been selected. The selected language of publication was English since it is the most dominant language in social sciences articles (Hamel 2007).

Standard bibliometric methods allow the aggregation and process of data of articles over a period of time which includes of more years (Heradio \& Perez-Morago, et al., 2016; Li \& Zhao, 2015a; Ma et al., 2016a; Rey-Martí, Ribeiro-Soriano, \& Palacios-Marqués, 2016a).

\section{Results}

\subsection{Publication Pattern}

Main information, source growth, annual scientific production, most relevant sources, top 20 authors and top 20 Universities cited had been analyzed to identify the publication pattern.

In Table 1 we can find the main information regarding the 788 articles included in the research. 
Table 1. Main information

\begin{tabular}{ll}
\hline Description & Results \\
\hline MAIN INFORMATION ABOUT DATA & \\
Timespan & $2000: 2021$ \\
Sources (Journals, Books, etc.) & 344 \\
Documents & 788 \\
Average years from publication & 4,04 \\
Average citations per documents & 7,838 \\
Average citations per year per doc & 1,799 \\
References & 29452 \\
DOCUMENT TYPES & \\
article & 528 \\
article; book chapter & 24 \\
article; early access & 36 \\
article; proceedings paper & 5 \\
book review & 4 \\
editorial material & 2 \\
editorial material; early access & 1 \\
proceedings paper & 174 \\
review & 12 \\
review; early access & 2 \\
DOCUMENT CONTENTS & \\
Keywords Plus (ID) & 1072 \\
Author's Keywords (DE) & 2431 \\
AUTHORS & \\
Authors & 4772 \\
Author Appearances & 10548 \\
Authors of single-authored documents & 147 \\
Authors of multi-authored documents & 4625 \\
AUTHORS COLLABORATION & \\
Single-authored documents & 168 \\
Documents per Author & 0,165 \\
Authors per Document & 6,06 \\
Co-Authors per Documents & 13,4 \\
Collaboration Index & \\
\hline & \\
\hline &
\end{tabular}

Source: personal elaboration

As it could be observed, articles (528) and proceeding papers (174) are the most relevant type of documents followed by early accesses (36) and book chapters (24). On average, most articles were the result of the work of multiple authors considering that only 168 documents, out of 788, were single-authored. Finally, the Collaboration Index which implies the total number of authors of multi-authored articles/total number of multi-authored articles, has a value of 7,46.

During the analyzed period (2000-2021), the publications on the theme heavily increased from 2012. The most relevant scientific production refers to two journals: International Journal of Islamic and Middle Eastern Finance and Management and Journal of Islamic Accounting and Business Research (Figure 3). 


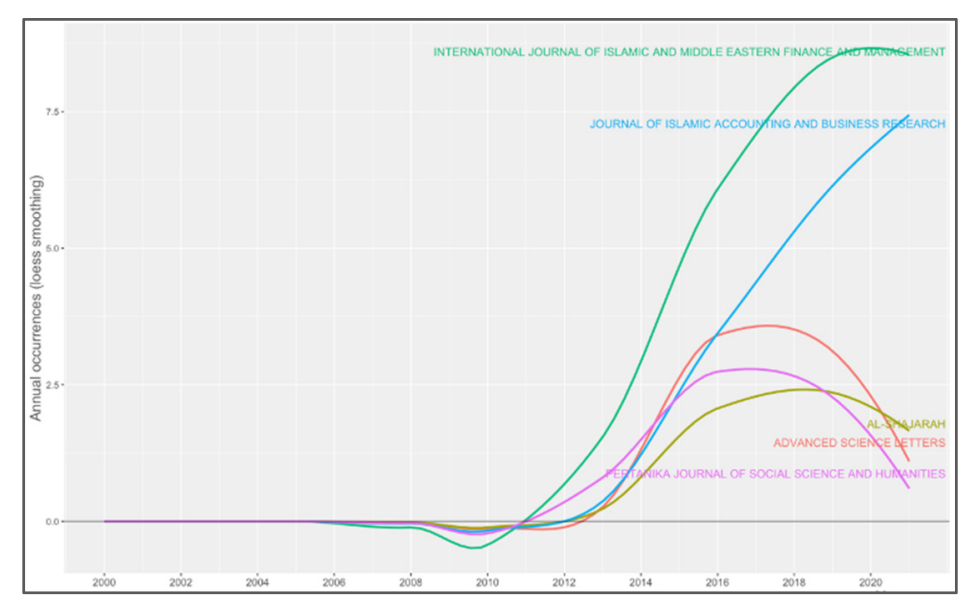

Figure 3. Source growth

Source: Personal elaboration from Biblioshiny.

Annual scientific production has increased consistently from 2008 with a maximum peak in 2020 (2021 has just started) (Figure 4). The results confirm that this field of research is continuously evolving and the future horizons are increasingly broad.

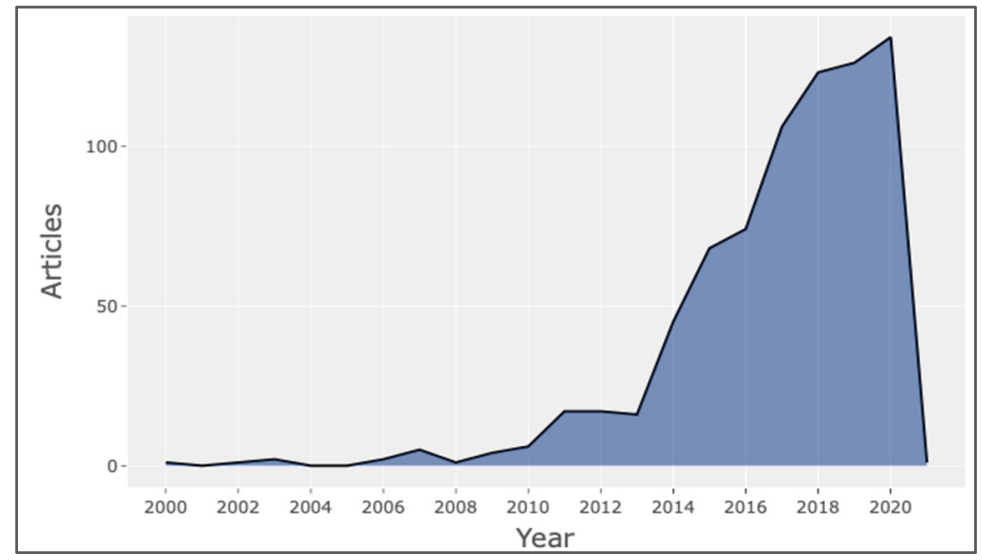

Figure 4. Annual scientific production

Source: Personal elaboration from Biblioshiny.

Observing the top 20 journals that published the analyzed articles, only eleven reach a relevant number of publications (Table 2), which together (253) represent more than one-third of the entire sample. Looking at the table below, it can be assumed that the observed journals are mainly related to Islamic finance issues and not generally to Social studies. 
Table 2. Top 20 most relevant sources

\begin{tabular}{ll}
\hline Sources & Articles \\
\hline International journal of Islamic and Middle Eastern finance and management & 64 \\
Journal of Islamic accounting and business research & 43 \\
Advanced science letters & 24 \\
Journal of Islamic marketing & 21 \\
Pertanika journal of social science and humanities & 19 \\
Al-shajarah & 17 \\
Humanomics & 16 \\
Isra international journal of Islamic finance & 16 \\
International journal of social economics & 12 \\
Journal of Asian finance economics and business & 11 \\
Intellectual discourse & 10 \\
Managerial finance & 9 \\
Journal of business ethics & 8 \\
Lancet & 8 \\
Research in international business and finance & 8 \\
International journal of finance \& economics & 7 \\
Pacific-basin finance journal & 7 \\
Sustainability & 7 \\
Emerging markets finance and trade & 6 \\
Ilc 2017 - 9th Uum International Legal Conference & 6 \\
\hline
\end{tabular}

Source: personal elaboration.

The sample is composed by 4772 authors. The authors with highest impact so far have been: HAJ-MIRZAIAN A (17) (medical researches), HASSAN MK (17) (expert in Islamic finance), GUPTA R (14) (medical researches), KASSIM S (14) (medical researches), SAMY AM (13) (medical researches), ABDULLAH A (expert in Islamic finance) (Table 3). Looking at the affiliation of the authors at the time of publication emerges that the most represented Universities are those on Table 4.

Most of the papers are the result of a group-work while only 168 had been the result of the work of a single author.

Table 3. Top 20 authors

\begin{tabular}{ll}
\hline Authors & Articles \\
\hline Haj-Mirzaian A & 17 \\
Hassan Mk & 17 \\
Gupta R & 14 \\
Kassim S & 14 \\
Samy Am & 13 \\
Abdullah A & 12 \\
Fischer F & 12 \\
Hendrie D & 12 \\
Jonas Jb & 12 \\
Jozwiak Jj & 12 \\
Murray Cjl & 12 \\
Rawaf Dl & 12 \\
Singh Ja & 12 \\
Aremu O & 11 \\
Behzadifar M & 11 \\
Bijani A & 11 \\
De Neve Jw & 11 \\
Fukumoto T & 11 \\
Hay Si & 11 \\
Majeed A & 11 \\
\hline
\end{tabular}


Table 4. Top 20 universities for scientific production

\begin{tabular}{ll}
\hline Affiliations & Articles \\
\cline { 2 - 2 } Univ Tehran Med Sci & 260 \\
Int Islamic Univ Malaysia & 169 \\
Kermanshah Univ Med Sci & 154 \\
Islamic Azad Univ & 129 \\
Univ Washington & 120 \\
Iran Univ Med Sci & 118 \\
Mazandaran Univ Med Sci & 91 \\
Harvard Univ & 85 \\
Univ Teknol Mara & 82 \\
Shahid Beheshti Univ Med Sci & 81 \\
Mekelle Univ & 76 \\
Tabriz Univ Med Sci & 71 \\
Univ Malaya & 70 \\
Babol Univ Med Sci & 66 \\
Univ Porto & 64 \\
Univ Oxford & 63 \\
Univ Utara Malaysia & 60 \\
Carol Davila Univ Med And Pharm & 56 \\
Imperial Coll London & 55 \\
Univ Melbourne & 54 \\
\hline
\end{tabular}

Source: personal elaboration

\subsection{Citation Analysis}

Figure 5 and Table 5 display the Country Production with Iran which tops the list (1257), the only one with more than 1000 citations, followed by Malaysia (952), USA (616), UK (383), Australia (355) and Ethiopia (304). This is due to the presence on that countries of a lot of scholars interested on the themes and demonstrates a remarkable development in the topic both in Muslim and non -Muslim countries even for different reasons. In fact, on the one hand, in Muslim countries Islamic finance is one of the most spread financial system since it complies with Saria law, so there is a certain academical discussion on this field and on recent times also in the field of social finance as a tool for growth and sustainable development. On the other hand, in USA, UK and Australia, Islamic finance is seen as an alternative financial tool with wide chances of growth (Belouafi \& Chachi, 2014; Rammal \& Zurbruegg, 2016). Finally, Figure 5 shows a generalized worldwide interest on the topic of research.

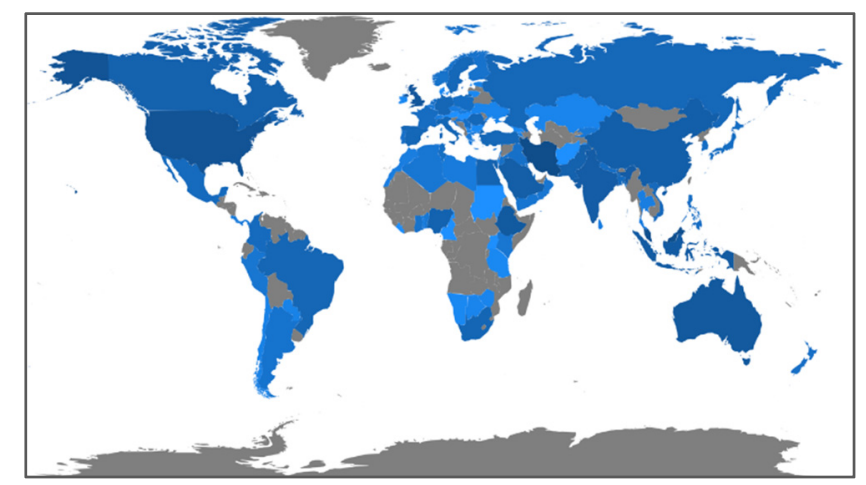

Figure 5. Country production

Source: personal elaboration 
Table 5. Top 20 country production

\begin{tabular}{ll}
\hline Region & Freq \\
\cline { 2 - 2 } Iran & 1257 \\
Malaysia & 952 \\
Usa & 616 \\
Uk & 383 \\
Australia & 355 \\
Ethiopia & 304 \\
Indonesia & 249 \\
India & 217 \\
Saudi Arabia & 194 \\
China & 177 \\
Canada & 136 \\
Pakistan & 130 \\
Nigeria & 113 \\
Egypt & 106 \\
Brazil & 87 \\
Germany & 83 \\
South Africa & 81 \\
Italy & 78 \\
Spain & 75 \\
Turkey & 72 \\
\hline
\end{tabular}

Source: personal elaboration

Table 6 represents the ranking of the top 20 articles per number of citations from other articles. This shows that the articles with more total citations and total citation per year are three papers edited in The Lancet. In particular, The Lancet has 3 papers in the Top-cited documents list and there are not journals with more than one citation in the list of most cited documents. The 5 most cited sources are:

- $\quad$ Lancet (2902),

- Abacus (152),

- Journal of Money Credit Bank (148),

- Emerging Market Review (126),

- $\quad$ Responsibility policy (1733).

However, observing the topic of all the journals and the contents of the articles, it must be underlined that, due to the wide settings of the initial research, it has been found that top-cited documents has been published on medical and engineering journals such as The Lancet, International Journal of Fuzzy Systems, Applied Thermal Engineering, International Journal of Intelligent Systems Volume and Nature. This result could be explained due to the presence of contributions of Islamic Scholars affiliated to Islamic Academical Institutions.

On the other hand, for what concerns the articles referrable to scientific journals of social and economic sector, it is possible to see that the highest number of references has been received by an article published in 2006 (Maali, Casson, \& Napier, 2006); this has been the most-cited article to date. Four articles, one done in 2011 (Hayat \& Kraeussl, 2011), one in 2014 (Al-Khazali, Lean, \& Samet, 2014), and two from 2018 (Hassan \& Aliyu, 2018; Kim, Yu, \& Hassan, 2018) have significant number of total citations per year and the overall ranking obtained in the top cited documents is probably due to the fact that they are more recent and consequently received, in proportion with the total time of circulation, a less number of total citations. This indicates that the papers provide high-quality information on issues related to Islamic finance and social finance. According to the results, it is not possible to identify a leading journal with a higher number of published articles inserted in the Top-cited documents list. 
Table 6. Top-cited documents

\begin{tabular}{|c|c|c|c|}
\hline \# & Authors, Titles and Sources & $\begin{array}{l}\text { Total } \\
\text { Citations }\end{array}$ & TC per Year \\
\hline 1 & $\begin{array}{l}\text { (James et al. 2018) Global, regional, and national incidence, prevalence, and } \\
\text { years lived with disability for } 354 \text { diseases and injuries for } 195 \text { countries and } \\
\text { territories, 1990-2017: a systematic analysis for the Global Burden of Disease } \\
\text { Study } 2017 \text {. } \\
\text { The Lancet - Volume 392, Issue } 10159,10-16 \text { November 2018, Pages 1789-1858 }\end{array}$ & 1437 & 359,25 \\
\hline 2 & $\begin{array}{l}\text { (Stanaway et al. 2018) Global, regional, and national comparative risk } \\
\text { assessment of } 84 \text { behavioural, environmental and occupational, and metabolic } \\
\text { risks or clusters of risks for } 195 \text { countries and territories, 1990-2017: a } \\
\text { systematic analysis for the Global Burden of Disease Study 2017. } \\
\text { The Lancet - Volume 392, Issue 10159, 10-16 November 2018, Pages 1923-1994 }\end{array}$ & 844 & 211 \\
\hline 3 & $\begin{array}{l}\text { (Kyu et al. 2018) Global, regional, and national disability-adjusted life-years } \\
\text { (DALYs) for } 359 \text { diseases and injuries and healthy life expectancy (HALE) for } \\
195 \text { countries and territories, 1990-2017: a systematic analysis for the Global } \\
\text { Burden of Disease Study 2017. } \\
\text { The Lancet - Volume 392, Issue 10159, 10-16 November 2018, Pages 1859-1922 }\end{array}$ & 553 & 138,25 \\
\hline 4 & $\begin{array}{l}\text { (Maali et al. 2006) Social Reporting by Islamic Banks. } \\
\text { Abacus } 2006 \\
\text { (Aggarwal e Yousef 2000) Islamic Banks and Investment Financing. }\end{array}$ & 152 & 9,5 \\
\hline 5 & $\begin{array}{l}\text { Journal of Money, Credit and Banking, Vol. 32, No. } 1 \text { (Feb., 2000), pp. 93-120 } \\
\text { ( } 28 \text { pages) }\end{array}$ & 148 & 6,7273 \\
\hline 6 & $\begin{array}{l}\text { (Hayat e Kraeussl 2011) Risk and return characteristics of Islamic equity funds. } \\
\text { Emerging Markets Review - Volume 12, Issue 2, June 2011, Pages 189-203 } \\
\text { (Al-Khazali et al. 2014) Do Islamic stock indexes outperform conventional stock }\end{array}$ & 126 & 11,4545 \\
\hline 7 & $\begin{array}{l}\text { indexes? A stochastic dominance approach. } \\
\text { Pacific-Basin Finance Journal - Volume 28, June 2014, Pages 29-46 }\end{array}$ & 108 & 13,5 \\
\hline 8 & $\begin{array}{l}\text { (Liu et al. 2018) Adaptive Controller Design for a Class of Uncertain } \\
\text { Fractional-Order Nonlinear Systems: An Adaptive Fuzzy Approach. } \\
\text { International Journal of Fuzzy Systems volume 20, pages366-379(2018) }\end{array}$ & 105 & 26,25 \\
\hline 9 & $\begin{array}{l}\text { (Pollard e Samers 2007) Islamic banking and finance and postcolonial political } \\
\text { economy: decentring economic geography. } \\
\text { Transactions of the Institute of British Geographers } 32 \text { 313-30 (2007) }\end{array}$ & 99 & 6,6 \\
\hline 10 & $\begin{array}{l}\text { (Maurer 2002) Anthropological and accounting knowledge in Islamic banking } \\
\text { and finance: rethinking critical accounts. } \\
\text { Journal of the Royal Anthropological Institute Volume8, Issue4 - December } 2002 \\
\text { - Pages 645-667 }\end{array}$ & 69 & 3,45 \\
\hline 11 & $\begin{array}{l}\text { (Chang et al. 2019) Measuring population ageing: an analysis of the Global } \\
\text { Burden of Disease Study } 2017 . \\
\text { The Lancet Public Health } \\
\text { Volume 4, Issue 3, March 2019, Pages e159-e167 }\end{array}$ & 68 & 22,6667 \\
\hline 12 & $\begin{array}{l}\text { (Kim et al. 2018) Financial inclusion and economic growth in OIC countries. } \\
\text { Research in International Business and Finance - Volume 43, January 2018, } \\
\text { Pages 1-14 }\end{array}$ & 45 & 11,25 \\
\hline 13 & $\begin{array}{l}\text { (Kamla e Rammal 2013) Social reporting by Islamic banks: does social justice } \\
\text { matter? } \\
\text { Accounting, Auditing \& Accountability Journal - Vol. } 26 \text { No. 6, pp. } 911-945\end{array}$ & 43 & 4,7778 \\
\hline 14 & $\begin{array}{l}\text { (Hassan e Aliyu 2018) A contemporary survey of islamic banking literature. } \\
\text { Journal of Financial Stability - Volume 34, February 2018, Pages } 12-43 \\
\text { (Rethel 2011) Whose legitimacy? Islamic finance and the global financial order. }\end{array}$ & 42 & 10,5 \\
\hline 15 & $\begin{array}{l}\text { Review of International Political Economy - Volume 18, } 2011 \text { - Issue 1: } \\
\text { Legitimacy and Global Governance Pages 75-98 }\end{array}$ & 39 & 3,5455 \\
\hline 16 & $\begin{array}{l}\text { (Tian et al. 2019) Risk-based stochastic scheduling of energy hub system in the } \\
\text { presence of heating network and thermal energy management. } \\
\text { Applied Thermal Engineering - Volume } 159 \text {, August } 2019,113825\end{array}$ & 37 & 12,3333 \\
\hline
\end{tabular}




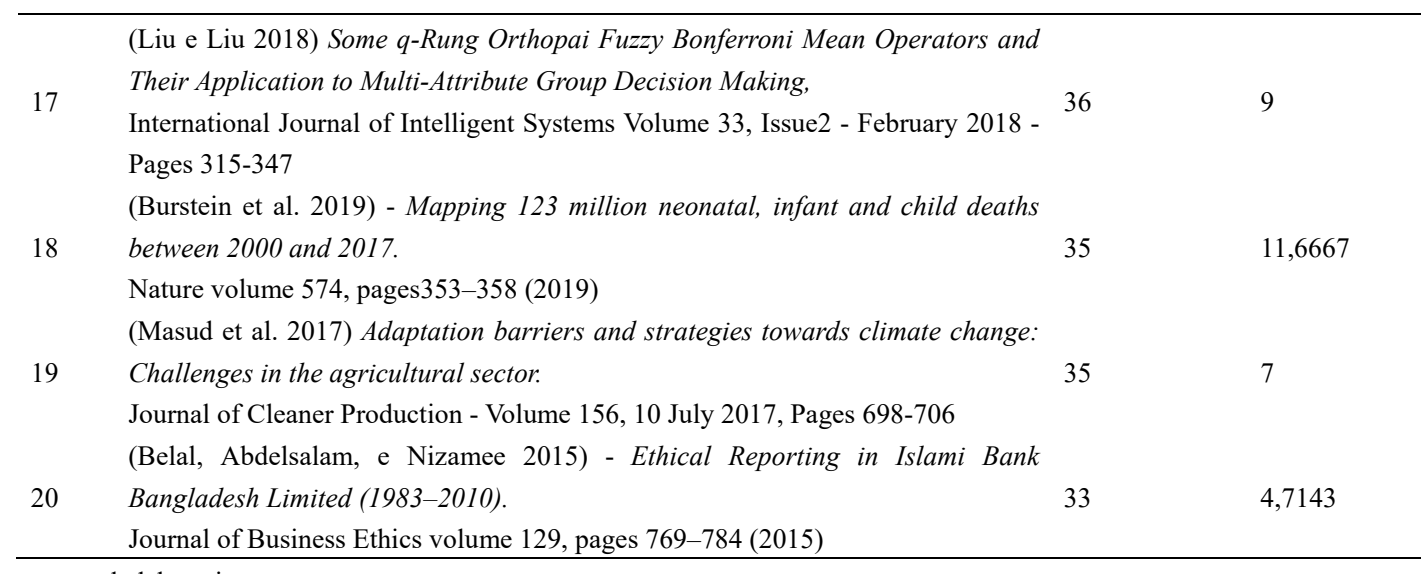

Source: personal elaboration

Topics analyzed from the considered articles are quite various, so for the purpose of this research, we will have a deepen look at the five most cited papers in the field of interest. The most relevant document is the one of Maali et al. (2006) in which the authors observe that "Islam stresses the concept of social responsibility. The term 'brotherhood' (Akhowa) is widely used in Islamic societies. All Muslims are considered to be brothers and should take care of each other, and no cheating or exploitation is allowed, whatever the reasons. Muslims are supposed to take care of others in society - the prophet Mohammed said: 'the Muslims in their mercy towards each other are like a body, if a single part of it complains the other parts would be affected' (Sahih Al-Bukhari-Ali, 1961). The prohibition of Riba (usury), the requirement to pay Zakah and the provision of Quard Hassan (interest-free loans) are clear examples of the Islamic emphasis on social justice. Islam also stresses that people should be dealt with justly: 'God commands justice, the doing of good' (Qur'an, 16:90). In this context, justice refers to being fair with everyone. Muslims are prohibited from engaging in any activity that includes any kind of exploitation, or leads to injustice or harm to anyone. As Ahmad (1995, p. 82) notes, 'Justice forms the core of the Quranic injunctions'. For Islamic businesses, the requirement to deal justly encompasses all dealings with employees, customers and all members of the society in which these businesses operate." and also "For pious Muslims, following the requirements of Sharia is central to life. In an Islamic context, the main objective of corporate reporting is to allow Islamic enterprises to show their compliance with Sharia (Baydoun \& Willett, 1997)." Furthermore, the conclusions are very interesting: "the empirical findings suggest that social issues are not of major concern for most Islamic banks. This may in part reflect the fact that most Islamic banks operate in less developed economies where social concerns, especially as regards issues such as the environment, may be given less importance (Belal, 2000). However, Muslims in the countries where Islamic banks operate are likely to have a high expectation of the banks' social role. This has been recognized by the management of some Islamic banks, such as Jordan Islamic Bank,11 and this bank provides a broader range of social disclosures compared to most other Islamic banks". (Aggarwal \& Yousef, 2000) examines the relationship between Islamic banking and investments stating that: "although Islamic banks are or should be based on the profit-and-loss sharing principle, given the economic environment in which they operate, using only this type of financing may not be possible. Moral hazard problems suggest the need for some sort of debtlike instrument. The use of markup contracts is a rational response to informational problems. Thus, we feel the informational environment will be a more important determinant of the evolution of banking and growth in Muslim countries than will attempt to impose financial systems based on specific religious principles".

Hayat and Kraeussl (2011) analyze the performance of Islamic equity fund (IEFs) over the period 2000-2009. An important implication of the research is that "Muslim investors might improve their performance by investing in index tracking funds or ETFs (Islamic exchange traded funds) rather than to invest in individual IEFs", in fact, "it seems that IEF managers have a long way to go, before offering Muslims an investment proposition that is attractive in terms of risk and return."

Finally, Al-Khazali et al. (2014) examine, through stochastic dominance (SD) analysis, that "whether Islamic stock indexes outperform conventional stock indexes by comparing nine Dow Jones Islamic indexes to their Dow Jones conventional counterparts: Asia Pacific, Canadian, Developed Country, Emerging Markets, European, Global, Japanese, UK, and US indexes. the concept of embeddedness in economic geography."; as a result of the analysis is stated that "Islamic investing performs better than conventional investing during meltdown economy". 


\subsection{Keyword Co-Occurrences Network}

Every article must contain keywords which represent the research fields that have been analysed in the articles. The purpose of the co-occurrence analysis is to design the conceptual structure of a frame of reference using a network of co-occurrence words to map and group the terms extracted from the keywords into a bibliographic collection (Alessandra et al. 2021). The following Figure 6 gives details to find out what are the fields of research that have been associate to social enterprises research. The figure evidences that scholars combine their scientific production with a relevant number of keywords and shows how the central role of PERFORMANCE, IMPACT and RISK. The world DETERMINANT could be difficultly contextualized without considering the specific framework in which it had been used in the articles.

Furthermore, the most relevant keywords are OWNERSHIP, CORPORATE SOCIAL-RESPONSIBILITY, MODEL, MANAGEMENT, BEHAVIOR AND EFFICIENCY.

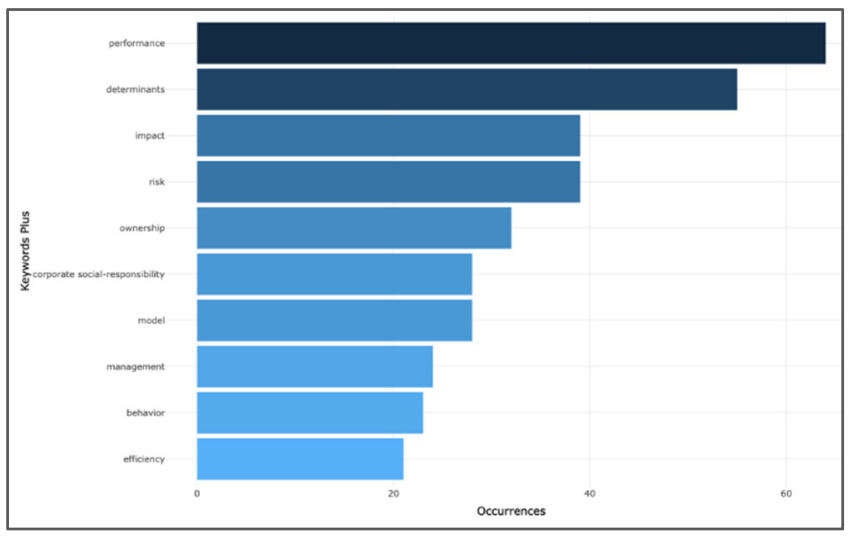

Figure 6. Most relevant words

Source: personal elaboration.



Figure 7. Annual occurrences of most cited words

Source: personal elaboration

The figure above shows the noticeable spread of the annual occurrences of the top cited words within the last 21 years. At the same time in Figure 8 and Table 7 below, clarify the trending topics between 2016 and 2020 , the years with the most relevant production. 


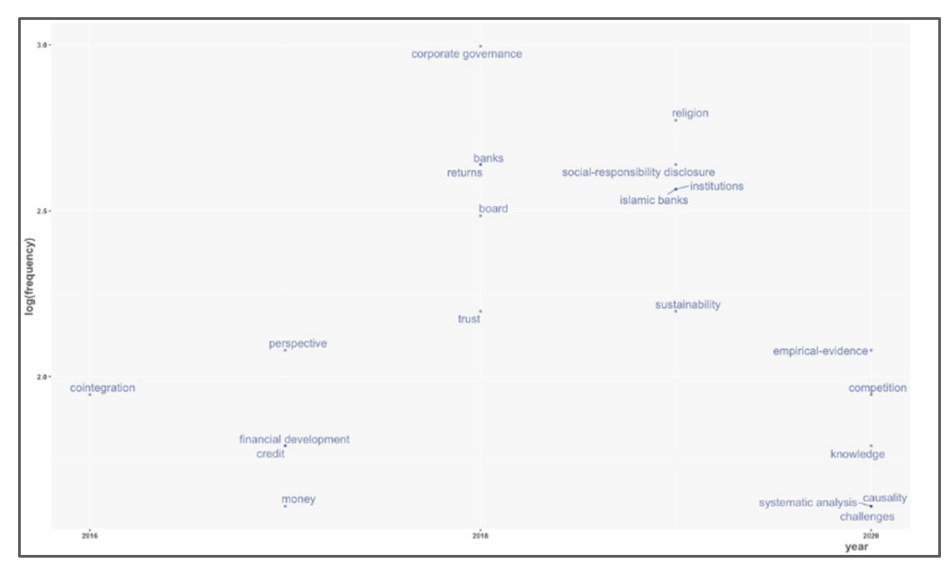

Figure 8. Trend topics per year

Source: Personal elaboration

Table 7. Trend topics per year

\begin{tabular}{lll}
\hline Words & freq & year \\
\hline Corporate Governance & 20 & 2018 \\
Religion & 16 & 2019 \\
Banks & 14 & 2018 \\
Returns & 14 & 2018 \\
Social-Responsibility Disclosure & 14 & 2019 \\
Institutions & 13 & 2019 \\
Islamic Banks & 13 & 2019 \\
Board & 12 & 2018 \\
Trust & 9 & 2018 \\
Sustainability & 9 & 2019 \\
Empirical-Evidence & 8 & 2020 \\
Perspective & 8 & 2017 \\
Competition & 7 & 2020 \\
Cointegration & 7 & 2016 \\
Knowledge & 6 & 2020 \\
Credit & 6 & 2017 \\
Financial Development & 6 & 2017 \\
Causality & 5 & 2020 \\
Challenges & 5 & 2020 \\
Systematic Analysis & 5 & 2020 \\
Money & 5 & 2017 \\
\hline
\end{tabular}

Source: personal elaboration

As it can be observed looking at Table 7, the top-3 relevant trend topics are related to Corporate Governance (20), Religion (16) and Banks (14). The most relevant contributions are analyzed below.

Corporate governance is analyzed by Fatemian and Rezaei (2018) with a particular focus on Iranian multinational and domestic companies listed in Teheran's stock exchange. Hassan e Aliyu (2018) analyze Islamic banks' performance and their impacts on social well-being, reviewing contemporary empirical studies of Islamic banks between 1983 and 2017. Nurim (2018) underlines the important role of local wisdom (Islamic Sharia in Indonesia) value to encourage the optimal financial company performance. The results show that local value has significant positive effect to financial performance and that corporate governance score insignificant different between the members of Jakarta Islamic Index and Non-Jakarta Islamic Index. The study contributes to the implementation of corporate governance practice, because it observes that the local wisdom value can become the social enforcement for management to behave ethically. Zainuldin, Lui, and Yii (2018) in their 
research find that "Islamic ethical system embedded in the Islamic banks business activities shapes Islamic banks into organizations that place higher ethical considerations than conventional banks. Therefore, Islamic banks are likely to have less severe agency problems relative to their conventional counterparts." Haridan, Hassan, and Karbhari (2018) find that the compliance review process is inadequately undertaken within SBs (Sharia boards) that are still excessively reliant on internal officers implying that there is a possible independence compromission. In particular, there are concerns about the value and effectiveness of SBs. The authors suggest that "This lack of confidence in the social aspect of Islamic banks need to be addressed with further improvement on the corporate governance". Al-Malkawi and Pillai (2018) in their paper observe "conventional corporate governance (CG) mechanisms into the Islamic banking framework in order to evaluate their impact on Islamic banks (IBS) financial performance (IBFP) within the Gulf Cooperation Council (GCC) context". Ajili and Bouri (2018) analyze "the role of Shariah Board (SB) that is considered as a typical corporate governance mechanism for the Islamic banking system because it takes the responsibilities of assuring the compliance of transactions and operations with Islamic rules and principles. In that paper the author measures the SB quality and examines its moderating effect on the relationship between financial performance and accounting disclosure quality". Barom (2018) examines "three major routes to normative justification of social responsibility: the objectives of Sharia (Maqasid al-Sharia), principles of Islamic moral economy (axioms of justice and beneficence) and micro-foundational assumptions (characteristics of homo Islamicus and the notion of falāh)". Nor, Nawawi, e Salin (2018) analyze the relation between efficient audit and positive investments. They observed that a company with strong governance structure will likely make better investment decision. In fact, "Managers under strong governance are prevented from taking an aggressive investment risk approach that may result in overinvestment. In addition, the company will carefully plan to have an adequate capital so that a good opportunity investment will not being passed due to insufficient financing that will result underinvestment". Bizri, Jardali, and Bizri (2018) investigate the role of non-economic factors on the financing decisions of family firms in the Middle East. "The findings imply that financing decisions which involve religious beliefs are directly influenced by the decision maker's personal attitude, which, in turn, is significantly influenced by familial and social pressures". Nomran, Haron, and Hassan (2018) analyze "the Malaysian declination of the Islamic financial rule that oblige Islamic banks (IBs) to stay Sharia compliant to enhance their customer loyalty and obtain a competitive edge. Given the performance of Sharia supervisory board (SSB) continues to be a matter of concern especially for IBS across countries that have a different regulatory environment, the authors examine the effects of SSB characteristics on IBs' performance in Malaysia being a country that applies the most extreme intervention of regulatory agencies (pro-active model)".

Religion becomes part of the academic discussion in that field, in particular with Fan et al. (2019) that provide credit risk analysis with cross country evidence from microfinance institutions (MFIs) that are Sharia-compliant and their comparisons with non-Sharia-compliant MFIs. They find that, compared with non-Sharia-compliant conventional MFIs, Sharia-compliant Islamic MFIs have less credit risk but are less profitable and financially sustainable, have better poverty outreach, and are less likely to 'mission drift'. The study highlights the differences in religiosity and security design between these two institutions and helps practitioners and policy makers to improve the understanding of the difference between conventional and Islamic MFIs. Boubakri et al. (2019), on the other hand, explore the stock liquidity of Islamic banks (IBs) matching conventional banks (CBs) in emerging economies, finding "that IBs have higher stock liquidity than CBs, suggesting that investors prefer IBs' stocks and neglect what they consider to be "sin stocks" (i.e., CBs' stocks), which do not conform to their religious beliefs." They also assumed that "faith-driven investors tend to value more norm-conforming stocks (i.e., IBs) during times of distress and uncertainty, and in weaker regulatory environments."

Majeed (2019) in his study analytically "explore and empirically test the relationship of social capital with economic performance of the Muslim world using Islamic perspectives and an inclusive development approach." With these premises, it is explained that social capital is an important cause of economic performance in the Muslim world.

Finally, Alazzani, Wan-Hussin, and Jones (2019) analyze "the state of the art of the researches devoted to answering the question of whether the religious beliefs of the upper echelons of management and gender diversity have any impacts on the communication of corporate social responsibility (CSR) information in the marketplace." The aim of the study is to fill the literature gap and to find an answer to two main questions "does the CEO religion affect a firm's CSR behaviour?" and "do the women on the boards influence CSR reporting?".

Banks are examined from Mansour e Bhatti (2018) under the new paradigm of Islamic corporate governance (ICG) in an emerging area of Islamic finance. The authors argue that ICG is no longer expected to play the traditional supervisory and regulatory role within Islamic financial institutions. In this sense, ICG must be seen 
under a "multi-faceted, new paradigm for the purpose of improving the stakeholders' interests and reaching the best business practices of the Islamic finance industry to cater investors' need and the social well-being of the homeless and disadvantaged communities". According to Al-Jarhi (2018), Islamic finance industry is composed of products with claim of Islamicity but questionable on their Sharia credentials. This in a context in which the industry is increasingly exposed to cynicism and decline in popular interest, facts these that need to be addressed and that require actions to change the actual route. (Hassan \& Aliyu, 2018) argue that Islamic banking system is performing below its conventional counterpart. (Isa et al., 2018) observe that "Malaysian banks are sufficiently provisioned for the regional financial integration under the ASEAN Capital Markets Forum (ACMF) by the end of 2015, where several initiates have been initiated, including the harmonization of standards to encourage greater intra-regional investment flows and transactions and continued provisions of the much-needed funds by the region's private sectors".

Al-Malkawi and Javaid (2018) investigate "the impact of corporate social responsibility (CSR) on corporate financial performance (CFP) using Zakat as a measure for CSR." In this study it is revealed that "there is a strong positive relationship between CSR (Zakat) and CFP which suggests that Zakat contributes positively to both firm's profitability and value and can be considered as a win-win strategy to maximize returns and improve performance while considering the society as a whole." Sarhan and Ntim (2018) suggest that greater efforts must be done towards pursuing reforms in MENA countries that seek to improve national governance quality, economic environment and positive religious practices.

Isa e Rashid (2018) observe that Islamic banks in Malaysia during a period of "distressed financial conditions were less discouraged to increase their regulatory capital funds to share risks. Intuitively, they were more encouraged to engage in risk-shifting behavior. Also, the risk-shifting behavior was found to have a significantly high potential in foreign-owned Islamic banks than in domestic Islamic banks". These observations imply that "Islamic banks can continue to play their role in promoting inclusive growth, reducing inequality and accelerating poverty reduction.".

Furthermore, the topic dendrogram (Figure 9) identifies five macro variables dominant in the field and used as keywords by authors. They are represented in hierarchical order and the relationship between the keywords generated by hierarchical clustering is represented too. The cut in the figure and the vertical lines facilitate an investigation and interpretation of the different clusters. According to Andrews (2003), Fig. 5 does not intend to find the perfect level of associations between clusters, but it aims to estimate the approximate number clusters in order to facilitate further discussion on the field of research.

Concerning the existing link between social finance and Islamic finance, the convergence is divided into two main strands. The first strand focuses on investments, debt, capital structure and firms, implying that there is a strong link with the bank and investment level, and the second strand focuses on aspects such as impact, management, corporate social responsibility (CSR), quality, social responsibility, growth and religion and still with the banking side with themes such as banking, finance, risk, markets, financial institution, agency cost, board, directors and efficiency.

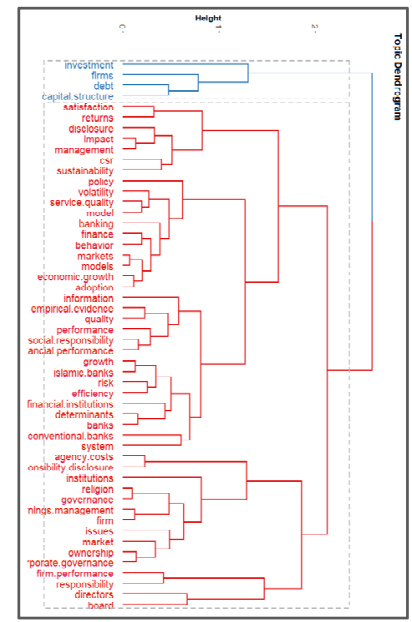

Figure 9. Topic dendrogram 


\section{Discussion and Conclusions}

\subsection{Literature Contribution}

To develop a sustainable international growth, in recent years mainstream finance and Islamic finance are moving their interests toward social issues. Social responsibility, as a matter of fact, represents a relevant part of the academical debate. For this reason, it has been considered that a bibliometric analysis of the relationship between Islamic finance and social finance could have been the right starting point for further systematic studies of this fast-growing area of finance.

As a matter of fact, Islamic finance, due to its adherence to the Shaaria and Quran's principles, has its own set of ethical and social characteristics, that have to be analyzed also from an academical point of view.

Islamic finance, in fact, is based upon 10 main rules which are strongly linked to social responsibility in financial environment (Schoon 2015):

- Avoid riba;

- Avoid gharar;

- $\quad$ Trade honestly and fairly;

- Full disclosure;

- Avoid misrepresentation;

- Do not interfere in a transaction that is (being) concluded;

- $\quad$ Avoid haram (forbidden) items;

- No hoarding;

- Open markets;

- Do not take advantage of a seller's helplessness.

These principles, in fact, are similar to those that can be found in the mainstream Social Responsible Investing (SRI) market and in some western financial regulations such as the UK's Treating Customer Fairly (TCF). The main difference between Islamic and main stream social principles is that Islamic principles apply to all parties instead TCF applies only to customers.

Starting from that general considerations and having a look at the trending topics of the last 5 years, it is clear that academics are underlining very important concepts useful for the diffusion of social finance practices in a system that seems to be the natural environment for social responsibility and social and sustainable development. Social responsibility, sustainability, trust and challenges are the most relevant words in that sense. Even if in that paper it doesn't clearly emerges an explicit reference to the SDGs (Sustainable Development Goals), it seems that Islamic finance could be a very effective instrument to the achieve that goals.

The research shows the results of 21 years of academic contribution in the field of Islamic finance and social finance and could be considered as the starting point to deepen on the fields of knowledge that has emerged from the bibliometric analysis.

A bibliometric analysis has been used to map the patterns and characteristics of 788 contributions published worldwide in proceedings papers, books chapters and reviews, international academic journal and editorial materials. This scientific method allows the analysis to grant a deeper understanding of the state of art of the research on the field of the relation between Islamic finance and social finance. The main finding is the presence of a number of keywords which link Islamic finance, social finance and sustainable development goals. Another important finding is the diffusion of this academic issue not only in Muslim countries but also in USA, UK and Australia which seem to have a certain attention toward Islamic Finance both from an academical and financial point of view.

The bibliometric analysis showed that the most cited articles are very old compared to the relevant academical production of the last five years. However, these articles are really interesting in the way they stress their focus on actual issues such as:

- $\quad$ The link between social responsibility and justice in Islamic finance and the implications of that relation in social reporting in Islamic banks;

- Doubts on the sustainability of a profit and loss sharing system such as those conducted by Islamic banks;

- $\quad$ The higher efficiency of Islamic ETFs compared to the performance of IEFs (Islamic Equity funds); 
- The over performance of Islamic stock indexes compared to their conventional counterparts during the 2008 world crisis.

\subsection{Implications for Institutions, Banks, Enterprises and Customers}

Starting from the study's preliminary evidences and if supported by future research, Islamic finance and Social finance have demonstrated a proven relevant relation which can be enhanced by all levels of stakeholders, from governments, to banking institutions, to social enterprises, to SMEs and also to customers. However, they have to coordinate their actions in order to generate a positive impact both from a social and economic point of view.

Islamic social finance is a reality and the academical and economic discussion on that field which is continuously growing. It implies that it is time to boost the output of that relation also considering that a shared action of Islamic finance actors in the social finance fields will enhance ethical investments that will generate economic activities able to create social impact also helping people in need. Despite the fact that Muslim countries may have seen a deeper relation between Islamic finance and its social output, however these countries have suffered a lack of coordination between banking and social institutions and often failed in the past to convey money in social projects (Olanrewaju, Shahbudin, \& Zakariyah, 2020). In non-Muslim countries, on the other hand, there is a higher awareness on the field of social finance but the countries usually fail to attract Islamic finance investments, due to their legislation which is not completely ready to welcome Islamic finance tools, so loosing huge amounts of money that could enhance their economy and the condition of local Muslims (Alharbi, 2016; Biancone, 2014; Biancone, Secinaro, \& Radwan, 2020; Grassa \& Hassan, 2015; Kalimullina, 2020; Masiukiewicz, 2017).

Particularly in a period of deep crisis, from an economic, environmental and social point of view, it seems very important to invest on sustainable development systems in which Islamic finance as social finance perfectly fits. The results suggest that the attitude toward that issue is changing and that it could be time to invest and bet on that field. Academic sector, in fact, is shading some light on the possible outputs of Islamic finance as social finance which implies that there is more consciousness on the challenges and the possibilities that now are ready to find practical application on real economy (Al-Roubaie \& Sarea, 2019; Atah, Nasr, \& Mohammed, 2018; Khan, 2019; Moghul \& Safar-Aly, 2014; Sekreter, 2017).

\subsection{Limitations and Future Research}

The paper's main limitation is due to the adoption of the bibliometric method because the databases include only part of the scientific papers and not all world's sources. However, WOS database, the one adopted for the research, is the world's most complete index even though it is not complete at all. On the other hand, to have a wider landscape of knowledge on the field of research, they have been considered all kind of sources: papers published in international and academic journals, books chapters and reviews, editorial materials and proceedings papers. The implications for academics, institutions, banks, enterprises and customers seem to be very relevant because it is assumed that a lot of work on the field must be done to strengthen the practical relation between Islamic finance and social finance.

The results suggest that in general there is a new awareness on the specific field of interest, as demonstrated by the analysis of the last 21 year's literature and that there are the basis for a general reflection on the possible opportunities of taking advantage of Islamic finance for social purposes.

In conclusion, observing that the originality of the paper lies on the fact that there are no other bibliometric analysis on this field and with the aim of demonstrating the connection between Islamic finance and social finance, this research confirms the initial questions and shows really interesting outputs for a huge number of stakeholders that can make a lot of work in the future in order to create value from social and sustainable activities.

\section{References}

Aggarwal, R. K., \& Yousef, T. (2000). Islamic Banks and Investment Financing. Journal of Money Credit and Banking, 32(1), 93-120.

Ajili, H., \& Abdelfettah, B. (2018). Assessing the moderating effect of Shariah Board on the relationship between financial performance and accounting disclosure. Managerial Finance, 44(5, SI),570-89. https://doi.org/10.1108/MF-05-2017-0192

Alazzani, A., Wan, N. W. H., \& Michael, J. (2019). Muslim CEO, women on boards and corporate responsibility reporting: some evidence from Malaysia. Journal of Islamic Accounting and Business Research, 10(2), 274-296. https://doi.org/10.1108/JIABR-01-2017-0002 
Alessandra, F., Barreca, M., Iannaci, D., \& Lanzara, F. (2021). The Impact of Social Enterprises: A Bibliometric Analysis from 1991 to 2020. International Journal of Financial Research, 12(3), 421. https://doi.org/10.5430/ijfr.v12n3p421

Alharbi, A. (2016). Development of Islamic Finance in Europe and North America: Opportunities and Challenges. International Journal of Islamic Economics and Finance Studies, 2(3), 109-36.

Al-Jarhi, M. (2018). Islamic Finance at Crossroads. Intel Lectual Discourse, 26(SI), 431-62.

Al-Khazali, O., Hooi, H. L., \& Anis, S. (2014). Do Islamic Stock Indexes Outperform Conventional Stock Indexes? A Stochastic Dominance Approach. Pacific-Basin Finance Journal, 28, 29-46. https://doi.org/10.1016/j.pacfin.2013.09.003

Al-Malkawi, H. A. N., \& Rekha, P. (2018). Analyzing financial performance by integrating conventional governance mechanisms into the GCC Islamic banking framework. Managerial Finance, 44(5, SI), 604-23. https://doi.org/10.1108/MF-05-2017-0200

Al-Malkawi, H. A., \& Saima, J. (2018). Corporate Social Responsibility and Financial Performance in Saudi Arabia: Evidence from Zakat Contribution. Managerial Finance, 44, 648-64. https://doi.org/10.1108/MF-12-2016-0366

Al-Roubaie, A., \& Adel, S. (2019). Building Capacity for Green Economy: The Role of Islamic Finance. TAFHIM: IKIM Journal of Islam and the Contemporary World, 12(2).

Andrews, J. E. (2003). An author co-citation analysis of medical informatics. Journal of the Medical Library Association, 91(1), 47-56.

Anon, S. D., \& Furrer, E. A. (2008). Ijmr-libre Strategic Management Cognitive Science. Retrieved from https://www.scribd.com/document/213659880/Furrer-Et-Al-2008-Ijmr-libre

Aria, M., \& Corrado, C. (2017). Bibliometrix: An R-Tool for Comprehensive Science Mapping Analysis. Journal of Informetrics, 11(4), 959-975. https://doi.org/10.1016/j.joi.2017.08.007

Atah, U. I., Wafa, M. A. N., \& Mustafa, O. M. (2018). The Role of Zakat as an Islamic Social Finance towards Achieving Sustainable Development Goals: A Case Study of Northern Nigeria.

Barom, M. N. (2018). Conceptualizing a unified normative framework for social responsibility in islamic economics.

Baydoun, N., \& Willett, R. (1997). Islam and Accounting: Ethical Issues in the Presentation of Financial Information. Accounting, Commerce and Finance: The Islamic Perspective, 1(1), 1-25.

Belal, A. R. (2000). Environmental Reporting in Developing Countries: Empirical Evidence from Bangladesh. Eco-Management and Auditing, 7(3), 114-21. https://doi.org/https://doi.org/10.1002/1099-0925(200009)7:3<114::AID-EMA131>3.0.CO;2-E

Belal, A. R., Omneya, A., \& Sardar, S. N. (2015). Ethical Reporting in Islami Bank Bangladesh Limited (1983-2010). Journal of Business Ethics, 129(4, SI), 769-784.

Belouafi, A., \& Abdelkader, C. (2014). Islamic Finance in the United Kingdom: Factors Behind Its Development and Growth. SSRN Scholarly Paper. Rochester, NY: Social Science Research Network.

Biancone, P. P. (2014). Islamic Finance: What Is the Outlook for Italy? International Journal of Economics and Management Engineering, 8(2), 6.

Biancone, P. P., \& Maha, R. (2018). Social Finance and Unconventional Financing Alternatives: An Overview.

Biancone, P., Silvana, S., \& Maha, R. (2020). Compatibilità della finanza islamica alla normativa italiana. Stato, Chiese e pluralismo confessionale. https://doi.org/10.13130/1971-8543/13415

Binmahfouz, S. (2012). Investment Characteristics of Islamic Investment Portfolios: Evidence from Saudi Mutual Funds and Global Indices. Doctoral, Durham University.

Bizri, R., Rayan, J., \& Marwa, F. B. (2018). Financing family firms in the Middle East: the choice between Islamic and conventional finance. International Journal of Entrepreneurial Behavior \& Research, 24(4), 842-865. https://doi.org/10.1108/IJEBR-10-2016-0349

Boubakri, N., Ruiyuan, C., Omrane, G., \& Xinming, L. (2019). The Stock Liquidity of Banks: A Comparison between Islamic and Conventional Banks in Emerging Economies. Emerging Markets Review, 39, $210-224$. https://doi.org/10.1016/j.ememar.2019.03.006 
Cattelan, V. (2018). Islamic Social Finance: Entrepreneurship, Cooperation and the Sharing Economy. Routledge.

Chang, A. Y., Vegard, F. S., Stefanos, T., Nicholas, J. K., \& Joseph, L. D. (2019). Measuring Population Ageing: An Analysis of the Global Burden of Disease Study 2017. The Lancet Public Health, 4(3), 159-167. https://doi.org/10.1016/S2468-2667(19)30019-2

Crone, P. (2005). How did the quranic pagans make a living? Bulletin of the School of Oriental and African Studies-University of London, 68, 387.

Fan, Y., Kose, J., Frank, H. L., \& Luqyan, T. (2019). Security Design, Incentives, and Islamic Microfinance: Cross Country Evidence. Journal of International Financial Markets Institutions \& Money, 62, 264-280.

Farneti, F., Federica, C., Monica, M., \& Charl, V. (2019). The influence of Integrated Reporting and stakeholder information needs on the disclosure of social information in a state-owned enterprise. Meditari Accountancy Research.

Fatemian, F., \& Farzin, R. (2018). Capital Structure Determinants Inside Multinational and Domestic Companies: Evidence from Iran. Humanidades \& Inovacao, 5(2), 154-168.

Faturohman, T., Muammar, F. A. R., Raden, A. R., Asep, D., \& Kurnia, F. A. (2021). The Potential Role of Islamic Social Finance in the Time of COVID-19 Pandemic.

Ferro, N. (2005). Value Through Diversity: Microfinance and Islamic Finance and Global Banking. SSRN Scholarly Paper. Rochester, NY: Social Science Research Network.

Grassa, R., \& Kabir, M. H. (2015). Islamic Finance in France: Current State, Challenges and Opportunities. International Journal of Islamic Economics and Finance Studies, 1(1), 65-80.

Haji-Othman, Y., Mohd, F. A. L., \& Mohd, N. A. (2020). The Role of Islamic Social Finance in Reviving the Economy During COVID19 Pandemic Crisis.

Hajjar, M. (2019). Islamic Finance in Europe: A Cross Analysis of 10 European Countries. Springer.

Hamel, R. E. (2007). The Dominance of English in the International Scientific Periodical Literature and the Future of Language Use in Science. AILA Review, 20(1), 53-71. https://doi.org/10.1075/aila.20.06ham

Haridan, N. M., Ahmad, F. S. H., \& Yusuf, K. (2018). Governance, Religious Assurance and Islamic Banks: Do Shariah Boards Effectively Serve? Journal of Management \& Governance, 22(4), 1015-1043.

Hassan, M. K., \& Sirajo, A. (2018). A Contemporary Survey of Islamic Banking Literature. Journal of Financial Stability, 34, 12-43. https://doi.org/10.1016/j.jfs.2017.11.006

Hassan, M. K., Sirajo, A., \& Mumtaz, H. (2019). A contemporary review of islamic finance and accounting literature. The Singapore Economic Review, 1-38. https://doi.org/10.1142/S0217590819420013

Hayat, R., \& Roman, K. (2011). Risk and Return Characteristics of Islamic Equity Funds. Emerging Markets Review, 12(2), 189-203. https://doi.org/10.1016/j.ememar.2011.02.002

Heradio, R., Hector, P. M., David, F. A., Francisco, J. C., \& Enrique, H. V. (2016). A Bibliometric Analysis of 20 Years of Research on Software Product Lines. Information and Software Technology, 72, 1-15. https://doi.org/10.1016/j.infsof.2015.11.004

Heradio, R., Luis, T. C., Daniel, G., Francisco, C., Enrique, H. V., \& Dormido, S. (2016). Virtual and Remote Labs in Education: a Bibliometric Analysis. Computers \& Education, 98, 14-38. https://doi.org/10.1016/j.compedu.2016.03.010

Isa, M. Y. M., \& Md, Z. H. A. R. (2018). Regulatory Capital Funds and Risk-Sharing Behavior in Distressed Financial Conditions An Empirical Analysis on Islamic Banks in Malaysia. Journal of Financial Reporting and Accounting, 16(1), 197-216.

Isa, M. Y. M., Yap, V. C., David, Y. G. F., \& Md, Z. H. A. R. (2018). Determinants of Loan Loss Provisions of Commercial Banks in Malaysia. Journal of Financial Reporting and Accounting, 16(1), 24-48.

Joyce, P. (2015). Ewan Ferlie and Edoardo Ongaro, Strategic Management in Public Services Organizations: Concepts, Schools and Contemporary Issues. Local Government Studies, 1-3. https://doi.org/10.1080/03003930.2015.1103548

Kalimullina, M. (2020). Islamic finance in Russia: A market review and the legal environment. Global Finance Journal. https://doi.org/10.1016/j.gfj.2020.100534 
Kamla, R., \& Hussain, G. R. (2013). Social Reporting by Islamic Banks: Does Social Justice Matter? Accounting Auditing \& Accountability Journal, 26(6), 911-945.

Khan, T. (2019). Reforming Islamic Finance for Achieving Sustainable Development Goals. SSRN Scholarly Paper. Rochester, NY: Social Science Research Network.

Kim, D. W., Jung-Suk. Y., \& Kabir, H. M. (2018). Financial Inclusion and Economic Growth in OIC Countries. Research in International Business and Finance, 43, 1-14. https://doi.org/10.1016/j.ribaf.2017.07.178.

Li, W., \& Yang, Z. (2015a). Bibliometric Analysis of Global Environmental Assessment Research in a 20-Year Period. Environmental Impact Assessment Review, 50, 158-166. https://doi.org/10.1016/j.eiar.2014.09.012

Littlewood, D., \& Diane, H. (2018). Social Enterprise Resilience in Sub-Saharan Africa. Business Strategy \& Development, 1(1), 53-63. https://doi.org/10.1002/bsd2.11

Liu, H., Shenggang, L., Guanjun, L., \& Hongxing, W. (2018). Adaptive Controller Design for a Class of Uncertain Fractional-Order Nonlinear Systems: An Adaptive Fuzzy Approach. International Journal of Fuzzy Systems, 20(2), 366-379. https://doi.org/10.1007/s40815-017-0371-5

Liu, P., \& Junlin, L. (2018). Some $q$-Rung Orthopai Fuzzy Bonferroni Mean Operators and Their Application to Multi-Attribute Group Decision Making: $q$-rung orthopai fuzzy bonferroni mean operators. International Journal of Intelligent Systems, 33(2), 315-347. https://doi.org/10.1002/int.21933

Ma, Y., Ming, D., Kehua, Z., Carol, M., Jianping, L., \& Peter, M. W. (2016a). Publication Trends in Acupuncture Research: A 20-Year Bibliometric Analysis Based on PubMed. PLOS ONE, 11(12), 168123. https://doi.org/10.1371/journal.pone.0168123

Maali, B., Peter, C., \& Christopher, N. (2006). Social reporting by Islamic banks. Abacus-A Journal of Accounting Finance and Business Studies, 42(2), 266-89. https://doi.org/10.1111/j.1467-6281.2006.00200.x

Majeed, M. T. (2019). Social Capital and Economic Performance of the Muslim World Islamic Perspectives and Empirical Evidence. International Journal of Islamic and Middle Eastern Finance and Management, 12(4), 601-622.

Mansour, W., \& Ishaq, M. B. (2018). The New Paradigm of Islamic Corporate Governance. Managerial Finance, $44(5, \mathrm{SI}), 513-523$

Masiukiewicz, P. (2017). Expansion of Islamic Finance in Europe. Journal of Intercultural Management, 9(2), 31-51. https://doi.org/10.1515/joim-2017-0007

Masud, M. M., Mohammad, N. A., Muhammad, M., Hasanul, B., Rulia, A., Ferdous, A. A. S. A., \& Halima, B. (2017). Adaptation Barriers and Strategies towards Climate Change: Challenges in the Agricultural Sector. Journal of Cleaner Production, 156, 698-706.

Maurer, B. (2002). Anthropological and accounting knowledge in Islamic banking and finance: Rethinking critical accounts. Journal of the Royal Anthropological Institute, 8(4), 645-667. https://doi.org/10.1111/1467-9655.00127

Moghul, U. F., \& Samir, H. K. S. A. (2014). Green Sukuk: The Introduction of Islam's Environmental Ethics to Contemporary Islamic Finance. Georgetown International Environmental Law Review, $27,1$.

Mohamad, S. (2014). Is Islamic Finance, Social Finance? Journal of Emerging Economies and Islamic Research, 2(2), 1-5. https://doi.org/10.24191/jeeir.v2i2.9619

Nawaz, H., Maira, A., Asma, S., \& Syed, M. H. B. (2019). Beyond Finance: Impact of Islamic Finance on Economic Growth in Pakistan. Economic Journal of Emerging Markets, 11(1), 8-18. https://doi.org/10.20885/ejem.vol11.iss1.art2

Nomran, N. M., Razali, H., \& Rusni, H. (2018). Shari'ah Supervisory Board Characteristics Effects on Islamic Banks’ Performance: Evidence from Malaysia. International Journal of Bank Marketing, 36(2), 290-304.

Nor, N. H. M., Anuar, N., \& Ahmad, S. A. P. S. (2018). The Impact of Audit Committee Independence and Auditor Choice on Firms' Investment Level. Pertanika Journal of Social Science and Humanities, 26(3), $1433-1454$.

Nurim, Y. (2018). The Effect of Local Value on Financial Performance in Digital Society Era.

Okoli, C., \& Kira, S. (2010a). A Guide to Conducting a Systematic Literature Review of Information Systems Research. SSRN Electronic Journal Sprouts: Working Papers on Information Systems. https://doi.org/10.2139/ssrn.1954824 
Okoli, C., \& Kira, S. (2010b). A Guide to Conducting a Systematic Literature Review of Information Systems Research.

Olanrewaju, A. S., Amirul, S. S., \& Habeebullah, Z. (2020). A Synthesis of the Islamic Social Finance for Sustainable Islamic Social Enterprise: A Four Factor of Production.

Patton, M. Q. (1999). Enhancing the quality and credibility of qualitative analysis. Health services research, 34(5 Pt 2), 1189.

Pollard, J., \& Michael, S. (2007). Islamic Banking and Finance: Postcolonial Blackwell Publishing Ltd Political Economy and the Decentring of Economic Geography.

Rammal, H. G., \& Ralf, Z. (2016). Awareness of Islamic banking products among Muslims: The case of Australia. Islamic Finance.

Rethel, L. (2011). Whose legitimacy? Islamic finance and the global financial order. Review of International Political Economy, 18(1, SI), 75-98. https://doi.org/10.1080/09692290902983999

Rey-Martí, A., Domingo, R. S., \& Daniel, P. M. (2016). A Bibliometric Analysis of Social Entrepreneurship. Journal of Business Research, 69(5), 1651-1655. https://doi.org/10.1016/j.jbusres.2015.10.033

Sarhan, A. A., \& Collins, G. N. (2018). Firm- and Country-Level Antecedents of Corporate Governance Compliance and Disclosure in MENA Countries. Managerial Auditing Journal, 33(6-7), 558-85.

Schoon, N. (2015). Islamic Finance as Social Finance.

Secinaro, S., Valerio, B., Davide, C., \& Paolo, B. (2020). Employing Bibliometric Analysis to Identify Suitable Business Models for Electric Cars. Journal of Cleaner Production, 264, 121503. https://doi.org/10.1016/j.jclepro.2020.121503

Sekreter, A. (2017). Green Finance and Islamic Finance. International Journal of Social Sciences \& Educational Studies, 4(3), 115-21.

Thompson, E. A. (2007). Misplaced Blame: Islam, Terrorism and the Origins of Hawala. Max Planck Yearbook of United Nations Law Online, 11(1), 279-305. https://doi.org/10.1163/18757413-90000009

Tian, M. W., Abdol, G. E., Kittisak, J., Marsel, K., Andrei, P., Nima, J., \& Sayyad, N. (2019). Risk-Based Stochastic Scheduling of Energy Hub System in the Presence of Heating Network and Thermal Energy Management. Applied Thermal Engineering, 159.

Torrey, C. C. (1892). The commercial-theological Terms in the Koran: a dissertation presented at the University of Strasburg. Leyden: Leyden: Brill.

Verbeek, A., Koenraad, D., Marc, L., \& Edwin, Z. (2002a). Measuring Progress and Evolution in Science and Technology - I: The Multiple Uses of Bibliometric Indicators. International Journal of Management Reviews, 4(2), 179-211. https://doi.org/10.1111/1468-2370.00083

Verbeek, A., Koenraad, D., Marc, L., \& Edwin, Z. (2002b). Measuring Progress and Evolution in Science and Technology - I: The Multiple Uses of Bibliometric Indicators. International Journal of Management Reviews, 4(2), 179-211. https://doi.org/10.1111/1468-2370.00083

Webster, J., \& Richard, W. (2002). Analyzing the Past to Prepare for the Future: Writing a Literature Review. MIS Quarterly, 26. https://doi.org/10.2307/4132319

Whitley, R. (2000). The Institutional Structuring of Innovation Strategies: Business Systems, Firm Types and Patterns of Technical Change in Different Market Economies. Organization Studies - ORGAN STUD, 21, 855-86. https://doi.org/10.1177/0170840600215002

World Bank \& Islamic Development Bank Group. (2017). Global Report on Islamic Finance 2016: A Catalyst for Shared Prosperity? The World Bank.

Zainuldin, M. H., Tze, K. L., \& Kwang, J. Y. (2018). Principal-Agent Relationship Issues in Islamic Banks: A View of Islamic Ethical System. International Journal of Islamic and Middle Eastern Finance and Management, 11(2, SI), 297-311.

Zupic, I., \& Tomaž, Č. (2015). Bibliometric Methods in Management and Organization. Organizational Research Methods, 18(3), 429-472. https://doi.org/10.1177/1094428114562629 


\section{Note}

Note 1. Ethical Investment Research Service (EIRIS, http://www.eiris.org/) defines a green or ethical SRI fund as a fund where the choice of investment is influenced by one or more social, environmental or another ethical criterion.

\section{Copyrights}

Copyright for this article is retained by the author(s), with first publication rights granted to the journal.

This is an open-access article distributed under the terms and conditions of the Creative Commons Attribution license (http://creativecommons.org/licenses/by/4.0/). 